\title{
Shiyang River ecosystem problems and countermeasures
}

\author{
Faming $\mathrm{Li}^{1,2^{*}}$, Guoqing $\mathrm{Zhu}^{3}$, Chunxiu Guo ${ }^{4}$ \\ ${ }^{1}$ Gansu Desert Control Research Institute, Lanzhou, China; ${ }^{*}$ Corresponding Author: faminglee@126.com \\ ${ }^{2}$ Gansu Minqin National Studies Station for Desert Steppe Ecosystem, Lanzhou, China \\ ${ }^{3}$ Gansu Key Laboratory of Desertification Combating, Gansu Desert Control Research Institute, Lanzhou, China \\ ${ }^{4}$ State Key Laboratory Breeding Base of Desertification and Aralian Sand Disaster Combating, Gansu Desert Control Research \\ Institute, Wuwei, China
}

Received 21 December 2012; revised 20 January 2013; accepted 27 January 2013

\begin{abstract}
With the increase of population and the development of social economy, contradiction between water supply and demand of Shiyang River Basin become more outstanding. Unreasonable exploitation and utilization of water resources cause the serious deterioration of ecological environment. According to the present ecoligical situation, by analyzing some actual problems of the ecosystem of Shiyang River Basin, a series of feasible control countermeasures are proposed. The article provide theoretical basis for the treatment and recovery of the degradation of ecological environment of Shiyang River Basin.
\end{abstract}

Keywords: Degradation of Ecological Environment; Water Resource; Ecological Water Use; Shiyang River; Minqin Oasis

\section{INTRODUCTION}

Shiyang River Basin in Arid Region of Hexi corridor, Gansu, Northwest China is one of the three inland river of Hexi Corridor. The river is guarding the gateway to the lower oasis stop the Tengger Desert and Badain Jaran Desert closure, which is Wuwei, Lanzhou, northern China and even the earth's natural barrier. In recent decades, due to rapid population growth and economic development, water supply and demand have become increasingly conspicuous in the upper and middle reaches of excess water, leading to the tributaries and the main river drying up. Usually only the upper reaches of the city sewage discharge and industrial waste water enters the river leading to gradual degradation, resulting in Shiyang River downstream oasis ecological environment deteriorated.

Ecological management and restoration of environ- mental degradation, ecological environment protection and reconstruction, does not only lead to the survival of the valley and economic development, but also to the northwest, northern China and improve the ecological environment. Therefore, the study of environmental degradation and ecological changes in the relation to water resources, proper understanding of the existing Shiyang River ecosystem issues, proposed countermeasures beneficial for ecological management and restoration of environmental degradation, protection of economic, social and ecological environment of river basin coordinated development is of great significance.

\section{AN OVERVIEW OF THE STUDY AREA}

Shiyang River originates a cold long ridge of the eastern section of Qilian Mountains, across the plains of the north flows through the corridor into the Minqin Hongyashan Gap, and finally vanishes into the desert. Upstream is the Qilian vein, middle high plains landscape dominated by Wuwei basin, downstream is mainly Alashan desert landscape, Minqin and Changning basin. The terrain which is higher in south and lower in north, from southwest to northeast tilt, it is a typical MountainOasis-Desert ecosystem.

The river length is $300 \mathrm{~km}$ with a basin area of 41,600 $\mathrm{km}^{2}$ and a total of eight major tributaries, from east to west includes Dajing River, Gulang River, Huangyang River, Zamu River, Jinta River, Xiying River, Dongda river and Xida River (Figure 1). Shiyang River Basin Water Resources total 1.659 billion $\mathrm{m}^{3}$, including surface water resources and natural surface water and groundwater resources in the amount of non-repetition. One surface natural water resources of 1.56 billion $\mathrm{m}^{3}$, and surface water quantity of groundwater resources are not duplicated 99 million $\mathrm{m}^{3}$. The basin is an independent closed inland river basin, forming the corridor plains between southern mountains and the northern desert area; an arid continental inland climate area, with less precipi- 


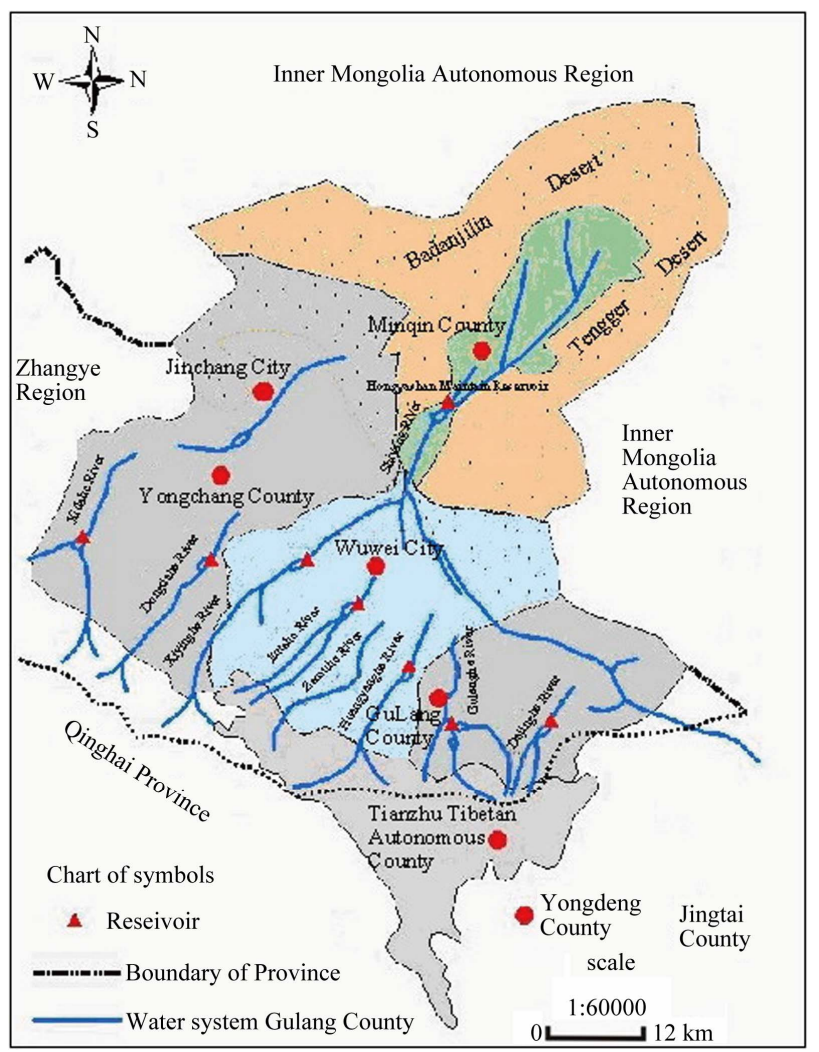

Figure 1. Water system of Shiyang River.

tation, precipitation variability, large uneven distribution during the year, evaporation, drought periods. This particular landscape and climate characteristics of the area of water resources are the most important eco-system factors.

Over the years, the utilization of water resources of Shiyang River was mainly for economic development of the agricultural sector, industrial use, and other aspects of water for human life. However, there has been an ignorance of the need to maintain ecological balance of the ecological environment of water. At the same time, a lot of overcapacity in groundwater resulted in regional groundwater level declining, Shiyang River downstream of natural groundwater recharge reduction, land desertification, salinization increased and vegetation degradation. This resulted in adverse consequences of the broken ring of the water-environment and water-ecology (Yang et al., 2002; Ding et al., 2003), and brought eco-logical and environmental problems [1,2].

\section{SHIYANG RIVER ECOSYSTEM AND CAUSES PROBLEMS}

\subsection{Water Shortages, the Obvious Contradiction between Supply and Demand}

Due to excessive grazing, deforestation and mining, increasing soil erosion, coupled with climate change in the upper reaches of Shiyang River; Dongda River, Qilian, Shangfang Temple, Sharma, Haxi, Wushaoling, Shibalipu, and Chang Ling mountain, several forest region are serious damaged, resulting in the decreased ability of water conservation of Qilian mountain, increased runoff amplitude (Figure 2), and decrease in Shiyang River Basin water inflow.

According to Shiyang River Basin Planning Report on Key Management (quote year published and page), there is currently a total basin gross water demand of 3.519 billion $\mathrm{m}^{3}$, from the total water supply of about 2.88 billion $\mathrm{m}^{3}$, leading to water shortage of about 639 million $\mathrm{m}^{3}$ [3]. At present the agricultural water consumption is 1.381 billion $\mathrm{m}^{3}$, for human life, industry, basic ecological water the consumption is 220 million $\mathrm{m}^{3}$, canal water evaporation losses, and other evaporation of 421 million $\mathrm{m}^{3}$, resulting in the total water consumption of 2.018 billion $\mathrm{m}^{3}$. River water was more than the status of basin water resources, water supply and demand contradiction is very conspicuous.

\subsection{Upstream Water Use Increased, Decreasing Runoff and Downstream, Upstream and Downstream Water Imbalance}

Qilian Mountains is the Shiyang River Basin Water Conservation District, and runoff areas, mainly chilling snow cushion vegetation and alpine meadows, scrub with North-Central Plain arid areas to the basic non runoff. River Oasis (basin) flow mainly from the upper reaches of mountain runoff, downstream Shiyang Oasis is downstream sink, terrain is a closed basin, and its most important water resources depends on the midstream and upstream water withdrawal flood. According to "Investigation of water resources in Wuwei” information, mountain

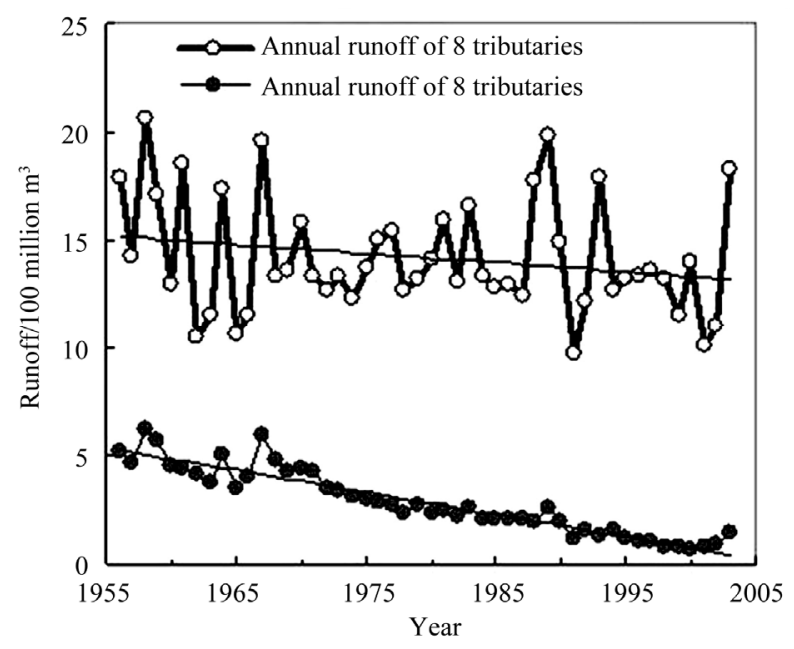

Figure 2. Change of runoff of Shiyang River and Hongyashan. 
region use water from the 5 million $\mathrm{m}^{3}$ of 50 years or so of the 20th century, to the late 80's 30 million $\mathrm{m}^{3}, 2006$ annual water consumption reached 36.2 million $\mathrm{m}^{3}$, making the pass the following oases reduction of available water resources [4]. Meanwhile, River irrigation area from the liberation(1949) of 110,000 ha has increase to 185,000 ha in 2003, an increase of 1.7 times, water consumption by nearly one-fold, leading to the Shiyang River Basin water resources utilization increases, reducing the amount of water into the Minqin Basin. Hongyashan Reservoir 50's water 464 million $\mathrm{m}^{3}$, to 90 's since the average runoff of about 120 million $\mathrm{m}^{3}$, in recent years, Minqin Oasis has an annually renewable water resources of about 150 million $\mathrm{m}^{3}$, and by the year 2000, Minqin Oasis Water is more than one-third that of 1957, resulting in the uneven distribution of water in the basin [5], and the growing imbalance in downstream water (Figure 3).

\subsection{Groundwater Level Decline, Deterioration of Water Quality, and Ecological Environment Degradation Exacerbates}

Groundwater regime change is the most direct reaction of the groundwater resources quantitative [6]. From 2003 the whole basin total water supply 2.877 billion $\mathrm{m}^{3}$, of which 1.089 billion $\mathrm{m}^{3}$ is for storage projects, the total amount of $37.85 \%$ water, 324 million $\mathrm{m}^{3}$ diversion project, accounting for $11.3 \%$, and groundwater engineering 1.447 billion $\mathrm{m}^{3}$, accounting for $50.3 \%$. Status of water, ground water supply ratio: 38:11:51, groundwater has been over $50 \%$ of the total water supply. Basin-wide groundwater overexploitation reached 432 million $\mathrm{m}^{3}$, of which 129 million $\mathrm{m}^{3}$ happened in middle Wuwei Basin, Minqin Basin 296 million $\mathrm{m}^{3}$ leading to groundwater level reduced significantly (Figure 4), decreased annual rate of up to $0.5-1 \mathrm{~m}$.

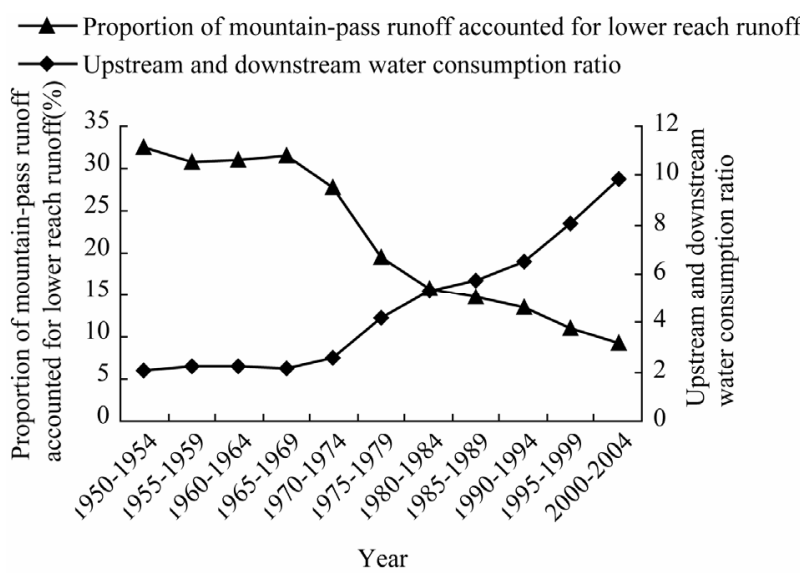

Figure 3. Average annual runoff in the lower reach of Shiyang River and upriver/downriver water consumption.
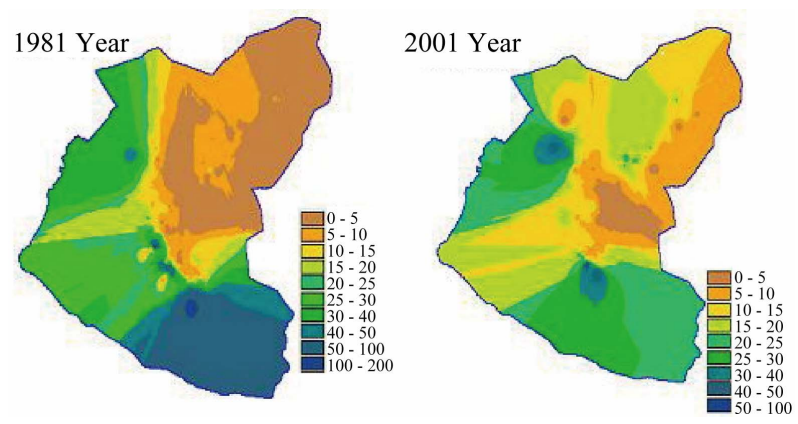

Figure 4. The change of ground water of Shiyang River.

Minqin had an irrigated area of about 40,000 ha in the mid-1980s to the mid-1990s, 80,000 - 17,000 ha, currently maintained at 67,000 ha. However, water volume has decreased year by year, and only rely on exploitation of underground water to sustain agricultural development. In Minqin, only Shajingzi for example, since the early 60 $\mathrm{s}$, there has been a significant decreased in water table and in the next 40 years, the groundwater level moved from $2.24 \mathrm{~m}$ down in 1961 to $17.96 \mathrm{~m}$ in 2001 . This represent a significant change in the groundwater level with the mean annual decline rate of $0.38 \mathrm{~m} / \mathrm{a}$ (Figure 5). Due to this continuous decline in groundwater level, Desert Area has been a serious threat to the ecological environment $[7,8]$. Groundwater level decline rate increased with the passage of years, 80 years ago (1961 to 1978), at $5.20 \mathrm{~m}$ above the groundwater level, the drop rate than the average decline rate. In the period of 10 years from 1978 to 1988 , the groundwater level was more than 9.0 $\mathrm{m}$, the decrease rate of consistent annual decline rate [9,10]. From 1988 to 2001, a period of 13 years, the groundwater level appeared to decrease twice the average rate of decline. Viewed from the oasis and oasis centre, the groundwater level farmland area decreased faster than the edge of the oasis and the desert area, desert area along the horizontal center of the oasis water gradually becomes deeper and forms a water table lower than the surrounding desert, and oasis center area of the water table as a funnel-shaped.

Declining groundwater levels, is leading to deterioration of water quality and increasing salinity. In Minqin, the overall variation of groundwater salinity is gradually increased, salt water area from northeast to southwest brought forward, fresh and brackish water in the area are narrowing. In addition, in Hongyashan Reservoir of Minqin Basin, the chloride content of the national standard is 1.2 - 4.5 times; the sulfate content is 1.7 - 8.2 times; the salinity is 1.6 - 6 times, and the total hardness is 2.0 - 5.7 times [11], particularly the areas of the lake basin sink and the northern desert edge of the village. TDS of groundwater in general is $4-6 \mathrm{~g} / \mathrm{L}$.

Over-exploitation of limited water resources led to a series of ecological and environmental problems, the 

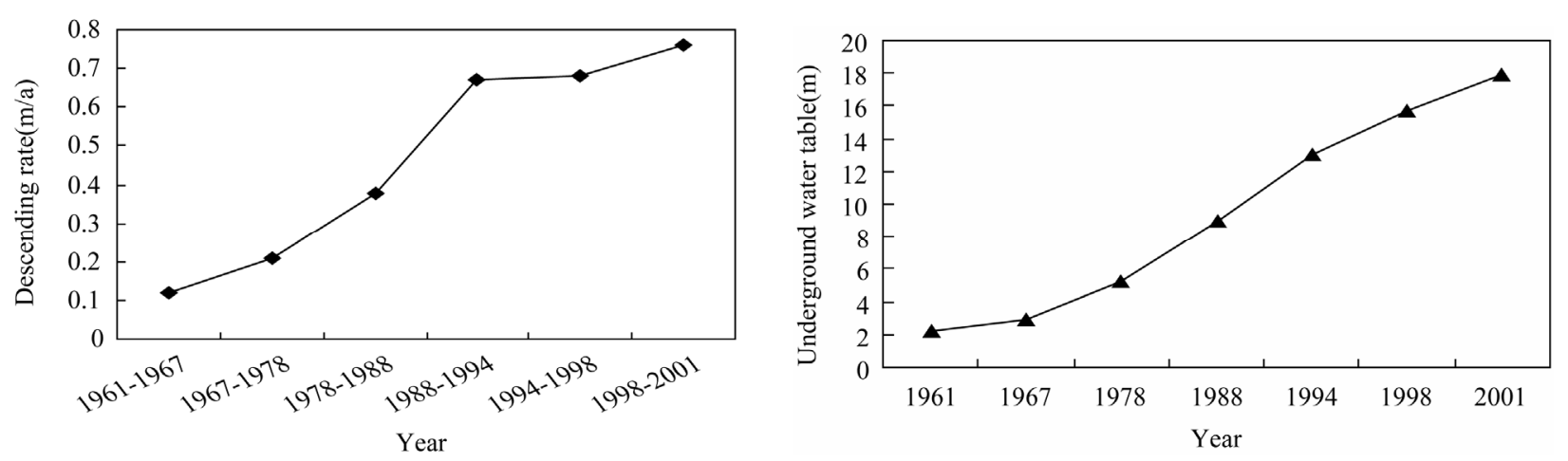

Figure 5. The decreases rang of underground water table in different in Shajingzi.

region's large area of land salinization and desertification which lead to soil degradation. As the groundwater and the large areas of vegetation decline, this caused the vegetation death, under the action of wind erosion, desertification, and salinization of the soil growing degree. For 50 years in the 20th century, a large number of wetlands were ecologically viable with in lowland plants, and canals along the lake, with a local coverage of more than $80 \%$, semi-fixed dunes were $30 \%$ and Nitraniria spp. about the health of the plant in recent wet series has gone ruins. There is $9000 \mathrm{hm}^{2}$ react with the decline of forest dieback, 23,300 $\mathrm{hm}^{2}$ of Nitraniria spp., Tamarix spp. and other natural vegetation is dead or half dead. Regarded as a protective barrier, the Oasis's "Chaiwan" vegetation is gradually shrinking. By the $50 \mathrm{~s}$ of 20th century, 133,000 hm "Chaiwan" vegetation was reduced to $71,200 \mathrm{hm}^{2}$ in 1995 with the loss of $62,100 \mathrm{hm}^{2}$. The natural bush has declined to $59,700 \mathrm{hm}^{2}, 38,700 \mathrm{hm}^{2}$ forest land lost and nearly $200,000 \mathrm{hm}^{2}$ of natural grassland decline [12]. Degradation of vegetation and sand dune activation resulted in the northern sand dunes of up to $3.6 \mathrm{~m}$ leading to an increased speed of the South, shifting sand burying beneath farmland of $26,700 \mathrm{hm}^{2}$, sandy area of 1.5801 million $\mathrm{hm}^{2}$, secondary salinization area of 52,000 $\mathrm{hm}^{2}$, an area of brackish water area $40,000 \mathrm{hm}^{2}$.

\subsection{Irrational Allocation of Water Resources, Use Efficiency Is Low, a Serious Lack of Water for Ecological Use}

Water resources are no longer maintaining the ecological and environmental deterioration and their gradual improvement, leading to the minimum required amount of water consumed. In the short-term, rate of investment return to ecology is minimum, with the water sector and farmers reluctant to invest in water conservation in terms of ecological construction. In particular, a serious shortage of such water resources in Shiyang arid zone, is increased due to industrial and agricultural production and living water use. The agricultural water use ratio is too large, constituting more than $90 \%$ of total water consumption, resulting in a serious shortage of water for ecological use. The following Minqin Oasis, for example, consumes 793 million $\mathrm{m}^{3}$ of the total water use in 2003, including industrial water 7 million $\mathrm{m}^{3}$, 776 million $\mathrm{m}^{3}$ for agricultural use, 10 million $\mathrm{m}^{3}$ for human consumption, and leaving the ecological water to 0 . Forecast down River of Minqin Oasis in the next 20 years, as the ecological environment had improved, 123 million $\mathrm{m}^{3}$ each year must be allocated for ecological water use, but in present water model, this water is extreme shortage [13]. Shiyang River Basin 2010 basic ecological net water demand, the gross water demand of 79.99 million $\mathrm{m}^{3}$, 129.64 million $\mathrm{m}^{3}$ respectively; And forecast of all levels of basic net and gross ecological water demand in 2020 will be 84.33 million $\mathrm{m}^{3}$, 132.85 million $\mathrm{m}^{3}$, respectively.

Shiyang River Basin water resources utilization of the existing structure of water is very low, with about 1.6 billion water resources $\mathrm{m}^{3}$, effective irrigation area of 233,300 ha, the net water use efficiency (water consumption and water ratio) of more than $95 \%$ far beyond the rational utilization of internationally recognized standards. Long-term irrigation as absolute ingredients to the level of the river basin within the irrigated area is too large, revaccination and interplanted ratio is too high, irrigation technology is relatively backward, irrational planting structure, resulting in low efficiency of agricultural water use, excessive consumption of water, serious ecological water diverted, leading to ecological deterioration. Over-exploitation of groundwater, especially in the case, some areas are still expanding arable land (Figure 6).

\section{IMPROVE THE RESPONSE OF ECOSYSTEMS SHIYANG RIVER}

Shiyang River Basin ecosystem of a number of issues, for the watershed and the ecological coordination of economic and social development, made the following countermeasures. 

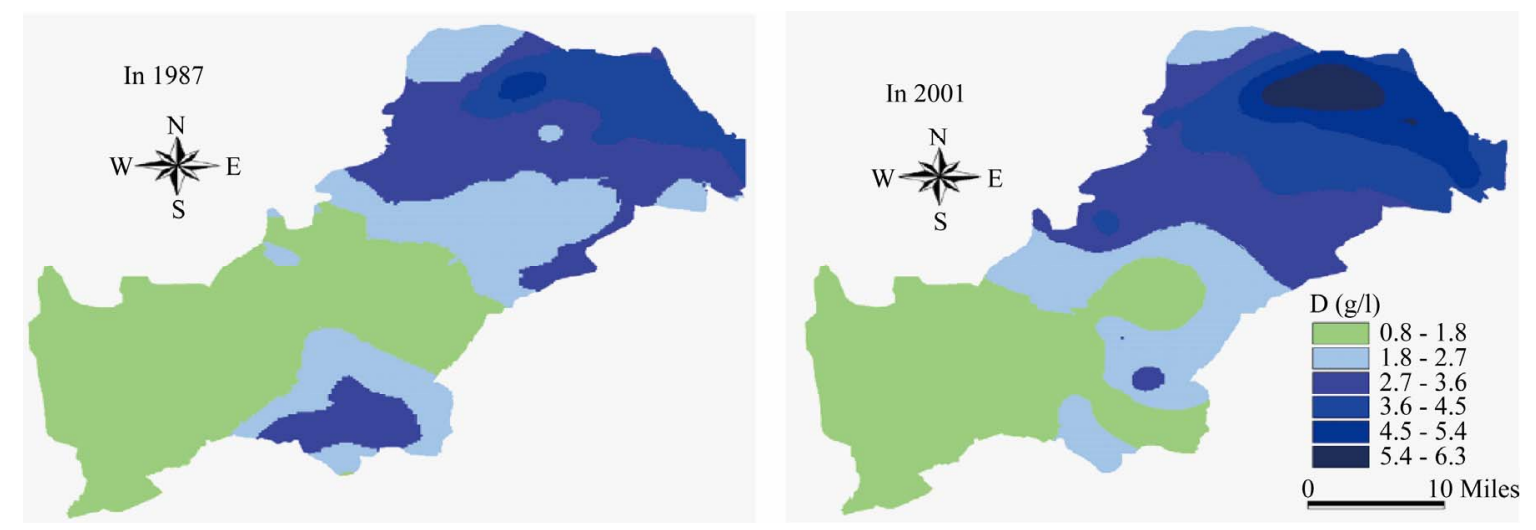

Figure 6. Groundwater mineralization map of Minqin oasis in 1987 and 2001.

\subsection{Optimization of Plant Structure, Promote Efficient Water-Saving Technology, Improve Water Use Efficiency}

Currently, the status of Shiyang River Basin water consumption is much greater than water supply, agricultural water use accounts for the main part, and the utilization of water resources extremely low, so the utilizetion of the limited water resources for the maximum benefits by introducing efficient agricultural water-saving techniques is an urgent task.

Firstly, integrated water resources allocation should be based on economic crops, pasture, and agricultural facilities, suitable crops comprehensive evaluation and selection. Ensuring food self-sufficiency in irrigation, and ecological and economic benefits must be increased by, engaging in ecological-economical irrigation planting structure optimization [14]. At the same time for the main types of field crops, carried out with the farming system of supplementary water saving irrigation technology, irrigation, irrigation water made elements and technical measures must be used. Agents of different types of soil moisture, water-absorbent polymers and to test the performance by steam to carry out leisure and crop growth period of adaptation experimental research, made all kinds of crops in arid environments soil moisture agent, insurance agent's application program, the formation of Shiyang River downstream of the efficient use of water resources and water-saving oasis ecological agriculture technical system.

On this basis, through the reform of the existing water resources management, and improving and supporting the field works, use of water-saving crop varieties, adjusting the agricultural structure and promote agricultural development of circular economy; to extend advanced irrigation technology, gradual development of modern and efficient water-saving agriculture. To seek ways to improve the unilaterally water efficiency and technology, groundwater and surface water combined use of tech- nology. Trial research and development as well as research on the oasis ecological environment change through the technology of water saving, structure of watersaving and water conservation, etc. Investigate the proportion of healthy the oasis ecological water and production water. To establish a highly efficient, water-saving oasis mode.

Through the efficient application of agricultural watersaving techniques such as reducing the irrigation canal (channel) which increases water evaporation and seepage water losses and improve irrigation water use efficiency; reduce the field of irrigation water to improve irrigation and reduce the quality of the water unit of irrigated area; reduce soil moisture evaporation loss, efficient use of natural precipitation and irrigation water; improve crop water productivity, reduce crop transpiration and water consumption of luxuries, get higher crop yield and water use efficiency, thereby enhancing the efficiency of water basin, so the limited water resources for maximum results. Studies have shown that, from the traditional maize in winter (spring) season to avoid storage reservoir pour, reducing winter irrigation water during fallow evaporation and increased rate of emergence of corn and improve water use efficiency, water conservation yield significantly. The technology can yield more than $15 \%$, saving water more than $16 \%$, water use efficiency by more than 25\%, water use efficiency of 3.7 RMB Yuan/ $\mathrm{m}^{3}$.

\subsection{Promotion of Artificial Ecological Restoration Technology, and Promote Restoration}

Because of scarce rainfall, strong evaporation, for a long time, Minqin region has always relied on upstream drain, or extraction of groundwater to maintain vegetation growth and development of the area. However, with the increased use of water resources in the upper and middle reaches of Shiyang for and economic development, the available water into the oasis is gradually de- 
creasing. Combined with human activities interference which leads to the drawdown of groundwater level, water quality deterioration a loss of natural vegetation, sandfixing and soil conservation capacity reduction of wind erosion have taken place in the dunes, mobile, severely affected and weakened the role of the oasis ecological barrier. In response to this situation, from the point of view of restoration ecology and ecohydrology must identify the key technologies appropriate to local ecological restoration.

Seed dressing live take aquasorb, mycorrhizal agent or insurance agent in the natural state, the the mycorrhiza agent seed dressing before rain timely aerial seeding artificial induction method, at the same time to take cover after planting, block and other management measures to promote the survival of seedlings. According to soil and vegetation to restore the principle of simultaneous functions to develop sustainable, relatively stable and consistent rain-fed areas of vegetation type distribution of desert vegetation as the goal, combined with local use of bio-engineering measures, Sediment Control key technologies, the establishment of artificial vegetation recovery system; on the combination of wind erosion in different areas of serious specification barrier against wind and sand, block sand bar, solid surface barrier rustle sand prevention measures and other projects. Existing research shows that white Nitronaria spp., Haloxylon spp. desert vegetation such as reliance on local $100 \mathrm{~mm}$ of annual rainfall, supplemented by artificial measures to restore vegetation cover to $30 \%$ or more, to meet the basic needs of desertification prevention and control. Therefore, the promotion of rain-fed eco-building techniques, can achieve 95\% of total land area of Minqin desert ecosystem restoration. For existing oasis, through the configuration shrubs and plants rain-fed desert vegetation, can reduce water consumption $20 \%$, while the appropriate replenishment of irrigation, to ensure full oasis ecological benefits. Minqin ecological restoration should adhere to the whole rain-fed, local replenishment policy, promotion of rain-fed large-scale ecological restoration techniques, to effectively improve the regional ecological environmental quality, protect the local ecological security, curb the desertification of the occurrence and development, coordination local agricultural and social development is very important.

By "the fenced grazing", "side of the membrane the rainwater harvesting coverage set moisturizing biological pad” create "artificial Tanegashima”, set "moisturizing bio-mat”, “concentrated drilling place a nutrition column reseeding technical measures" "patchy” rain-fed ecologicalsystems vegetation recover. Determine the ecological system configuration and proportion, structure and distribution of the sand-fixation plants proposed practical ecosystem management mode, restoration of degraded vegetation has a very important significance.

\subsection{Implementation of Industrial Restructuring, to Ensure the Most Basic Ecological Water Basin, on the Implementation of Integrated Management of Water}

Accelerate the pace of industrial restructuring, and actively promote the development of population, urbanization, increased second and third industry investment, increase employment opportunities, the population to the cities (towns) transfer; according to market demand and regional resources and conditions, the development of local industry, will enhance contribution to the national economy. Through the optimization of agricultural planting structure, control the scale of agricultural irrigation, increase the proportion of water-saving cultivation of cash crops, reducing agricultural water use, will assist increasing the availability of the ecological water [15]. Actively promote the house farming, to reduce grazing, and enhance the natural ecology of the self-recovery capability.

Characteristics of water resources required to establish the authority of a unified management system, which is the consensus of national and regional water shortage. The management of water resources can not stay in treatment, the lower the level of water disputes, water resources management to achieve change in water management, water use must be based on the populationeconomy-Resources - the principle of coordinated development of environment in the basin of the regions, departments need to optimize the water allocation of only 1.65 billion $\mathrm{m}^{3}$ of water to develop an operable upstream and downstream, departments, trade between the optimal water diversion, water distribution programs, to ensure water resources the sustainable use of [16]. To ensure the smooth flow of the entire basin, Shiyang, must control the scale of upstream irrigation and water consumption, guarantee that the discharging water, restore the river's minimum flow to meet the river evaporation, leakage and self-purification and other water demand, river restoration should be the core function. It is important to guarantee a certain amount of water downstream oasis to restore the original natural lakes and the natural vegetation to recover.

\subsection{Stop Groundwater Development, Protection of Watershed Economic, Social and Ecological Environment, Coordinated and Sustainable Development}

Shiyang River's average surface water resources is 1.56 billion $\mathrm{m}^{3}$, and surface water does not duplicate the 
amount of groundwater resources of 99 million $\mathrm{m}^{3}$, water resources total 1.659 billion $\mathrm{m}^{3}$, while the whole river basin in 2008 amounted to 2.686 billion in water supply $\mathrm{m}^{3}$, mainly overexploitation of groundwater project relies on a 1.035 billion $\mathrm{m}^{3}$. Under the current water system each year, ground water overexploitation amounts to 1 billion $\mathrm{m}^{3}$, and therefore in the water basin it is important to ensure the basic balance, over time, to reduce the declining groundwater levels. Therefore, we recommend should be based on basin water resources total 1.685 billion $\mathrm{m}^{3}$, re-planning of basin water resources utilization and balance, must stop the continued exploitation of groundwater in the middle and lower reaches, achieve basin-wide water balance, to protect the Minqin oasis ecological environment is no longer deteriorating, so that the coordination of the watershed economic and social and ecological environment sustainable development.

\section{REFERENCES}

[1] Yang, Y.C., Li, J.J., Chen F.H., Jacquie, B., Li, R.C., Li, D., Chang, G.Y. and Li, Y.C. (2002) The human mechanism research of Minqin oasis change in the lower reaches of the Shiyang river. Geographical Research, 21, 449-458.

[2] Ding, H.W., Wang, G.L. and Huang X.H. (2003) Runoff reduction into Hongyashan reservoir and analysis on water resources crisis of Minqin oasis. Journal of Desert Research, 23, 84-89.

[3] Li, S.M., Chen, G.D., Li, Y.H., et al. (2002) Rational utilization of water resource and protection of ecological environment in the Hexi corridor. Yellow River Water Conservancy Press, Zhengzhou, 76-249.

[4] Ma, G.J., Liu, J.D., Lin, D. and Chen, N.L. (2008) Status of water use and its eco-environmental effects in Shiyang river basin. Journal of Desert Research, 28, 592-597.

[5] Gao, Z.H., Ding F. and Wei, H.D. (2001) Actualities, cause and control of desertification in Hexi region, Gansu province. Journal of Natural Disasters, 10, 70-73.
[6] E, Y.H., Yan, P., Zhong, S. N. and Han, F.G. (1997) Study on the underground water variation of Shajingzi region in Minqin county. Journal of Desert Research, 17, 70-76.

[7] Sun, X.T. (2004) The history, present and future of water resources utilization in Minqin oasis. China Engineering Science, 6, 1-9.

[8] Song, D.M., Xiao, D.N., Zhang, Z.C., Cao, Y., Ma, M.G., Wang, J.H. and Wang, J. (2003) Landscape changes and its driving force of Minqin oasis in Gansu province. Chinese Journal of Applied Ecology, 14, 535-539.

[9] Yang, Y.C. (2003) The analysis of the oasis environmental change and its reason of the lower reaches of the arid region-A case study of Minqin county in the lower reaches of Shiymtg river in Hexi corridor, Gansu province. Human Geography, 18, 42-47.

[10] Yang, Z.H. and Gao, Z.H. (2000) Precipitation and groundwater effect of Nitraria community fluctuation in the edge of desert oasis. Chinese Journal of Applied Ecology, 11, 923-926.

[11] Wang, Q., Shi, J.A., Zhang, Z.N., et al. (2003) Shiyang river basin environmental status and trends of evolution. Journal of Desert Research, 23, 46-52.

[12] Yang, Z.H. (1999) Preliminary study on 40a desert vegetation change in Shajingzi area of Minqin county. Journal of Desert Research, 19, 395-399.

[13] Li, Y.H. and Li, X.L. (2006) Study on Minqin oasis ecological problems and solutions under the restriction of water conditions. Gansu Agriculture, 5, 121-122.

[14] Wang, H.Q., Cai, H.J. and Zhang, X. (2006) Study on ecological water Ddemand of Minqin oasis groundwater level restoration in Shiyang river. Soil and Water Conservation Bulletin, 26, 44-49.

[15] Li, F.M., Gao, Z.H. and Wu, C.R. (1995) The design of ecological and economic optimization model in Gansu Minqin desert control comprehensive experiment station. Pratacultural Science, 4, 59-63.

[16] An, F.B. and Ding, F. (2000) Minqin development trend of desertification and its control in Gansu province. Arid Land Resources and Environment, 14, 41-46. 